\title{
Cardiovascular disease versus periodontal disease: chronic systemic infection as a link.
}

\author{
R. Alonso-González ${ }^{1}$, A. Pérez-Hernández ${ }^{2}$, J. Silvestre-Rangil ${ }^{3}$, FJ. Silvestre ${ }^{4}$. \\ ${ }^{1}$ Bachelor of Dentistry. Post-graduate in Oral Surgery. Faculty of Medicine and Dentistry. University of Valencia. \\ ${ }^{2}$ Dentist, private practice (United Kingdom). \\ ${ }^{3}$ Dentist, private practice (Valencia). \\ ${ }^{4}$ Assistant Professor, Department of Stomatology, Valencia University Dental School. Head of the Stomatology Unit, Dr. Peset \\ University Hospital, Valencia.
}

Correspondence:

Unidad de Estomatología,

Hospital Universitario Dr. Peset (Consultas externas),

Juan de Garay s/n,

46017 Valencia (Spain)

Mail: francisco.silvestre@uv.es

Received: 16/05/2011

Accepted: $19 / 07 / 2011$
Alonso-González R, Pérez-Hernández A, Silvestre-Rangil J, Silvestre FJ. Cardiovascular disease versus periodontal disease: chronic systemic infection as a link. J Clin Exp Dent. 2011;3(5):e476-82 http://www.medicinaoral.com/odo/volumenes/v3i5/jcedv3i5p476.pdf (C) Medicina Oral S. L. C.I.F. B 96689336 - eISSN: 1989-5488 eMail: jced@jced.es

\begin{abstract}
Objective: Analysis of the alleged connection between the periodontal and cardiovascular disease, with reference to periodontal pathogens as a risk factor for heart disease.

Researching method: A research was carried out at Medline/Pubmed. Included criteria and researching strategy. The articles selection has been made taking into account key-terms appearing either in the title or in the summary. Experimental studies in animals, clinical prospective studies performed with a minimum sample size $(>30)$ and studies written in English have been included. The rejected criteria were the following: clinical retrospective studies and/or studies carried out with a low sample size $(\mathrm{n}<30)$.

Results: Within systemic diseases related to periodontal ones, the alleged link between periodontal and heart and circulatory disease has been one of the most investigated in recent times. Different authors consider the existence of a link between the diseases as such, inappropriate and implausible since both the diseases have risk factors in common (age, gender, smoking, diet, oral hygiene and diabetes). However, speculations about the origin of the diseases were raised when it was demonstrated that some bacteria species, bacteria proteins and lipopolysaccharide are present at the plaques of atherosclerosis that obstruct the coronary arteries. The mechanisms of this connection have been analyzed following an actualized review.

Conclusion: Most of the experimental and clinical studies ensure that a positive association between periodontal disease and heart disease has been found, once the con-founder factors have been eliminated.
\end{abstract}

Key words: Periodontal disease, cardiovascular disease, atheroma, oral pathogens, Actinobacillus Actinomycetemcomitans (Aa), Porphyromonas gingivalis (Pg). 


\section{Introduction}

In the last decade the expert's attention to the significance that oral health can have in atherosclerosis is raising. Cardiovascular diseases are secondary to atherosclerosis. Within cardiovascular diseases, heart related ones are noted. Ischemic cardiomyopathy is the most important sign that defines coronary artery disease $(1,2)$. Nowadays, heart diseases are the major cause of death in developed countries (1).

The classic risk factors related to these diseases have been identified as age, sex, heredity, diet, diabetes, high blood pressure, exercising and smoking. At present many studies show that inflammatory diseases with a chronic basis increase the risk of suffering from cardiovascular diseases. This is the reason why within the past decades researches on chronic infections effects on coronary pathogenesis have increased (3-6).

The mechanism whereby chronic infections increase the risk of suffering atherosclerosis or thrombosis is unclear, nonetheless it is believed that the requirement is a longterm systemic exposure to the pathogens (7-15).

A periodontal disease causes a sort of chronic inflammation (3) which provides bacteria and their components a direct access to the bloodstream, to which is added the micro ulceration of the epithelium of the periodontal pocket $(4,16,17)$. The contact between germs and macrophages causes a direct release of pro-inflammatory mediators (IL-8, TNF $\alpha$ ), that facilitates the attraction of neutronphils from vessels (innate immunity). The FNT $\alpha$ favors increased hepatic synthesis of LDL cholesterol. Equally, IL-6 is released later which helps the production of C-reactive protein (CRP) in the liver. This fact accellerates the atherosclerosis plaque progression.

Thereby, it seems that periodontal diseases could be an additional factor for the atherosclerosis development. Nevertheless, not all studies have stated that they have found causality, owing to the multi-factorial nature of both dental infection and cardiovascular disease and to the confusion factors adjustment that should be considered in every study. The primary aim of this review was to analyze the assumed connection between periodontitis and cardiovascular diseases. In this respect the analysis has been focused on the relevance of periodontal germs as a cardiovascular risk factor.

\section{Material and methods}

A research was carried out at Medline/Pubmed (http:// medline.cos.com) with the following keywords: oral pathogens OR Actinobacillus actinomycetemcomitans OR Porphyromonas gingivalis AND cardiovascular disease. Taken in criteria and research method: The articles selection has been made taking into account key-words either in the title or in the summary. Experimental studies in animals, clinical prospective studies performed with a minimum sample size $(>30)$ and studies written in En- glish have been included. Clinical retrospective studies, studies carried out with a low sample size $(\mathrm{n}<30)$ and non English language written studies were rejected.

\section{Literature review}

In the last decade, many epidemiological studies have brought to light that oral infections, especially $\mathrm{PD}$, can act as independent risk factor for several systemic diseases, like the CVD. It has been argued that mediators of inflammation in PD are the same involved in other chronic diseases such as CVD. The cause-effect relationship between the two processes is being studied with great interest (1). Inflammations appear to play a significant role in the pathogenesis of atherosclerosis. Low-grade chronic inflammatory processes could be involved in the development of this course. The PD is caused by a chronic infection associated with elevated CRP and other inflammatory biomarkers.

Histopathology and pathophysiology of atherosclerosis by periodontal inflammation: etiopathogenic models

When there is an initial damage of the endothelium, endothelial cells generate adhesion molecules called vascular cell adhesion molecules (VCAM) and intercellular adhesion molecules (ICAM) $(1,16,17)$. As a result the endothelium starts being attacked by leukocytes. Endothelial permeability to lipids (LDL cholesterol) increases, and production of cytokines/chemokines is enhanced as well as growth factors that at the same time stimulate monocytes/macrophages. Cytokines boost the attraction of polymorphonuclear cells (PMN) (2) as well, and the migration of smooth muscle cells, which respond to inflammatory stimuli by the secretion of metalloproteinases that are capable to degrade elastin and collagen $(18,19)$. Thereby, the fibrous capsule that maintained the plaque attached to the artery wall can break and detach, increasing in this way the risk of thrombosis, embolisms and strokes. Atherosclerosis is a chronic inflammatory disorder characterized by the accumulation of monocytes/macrophages, lipids (LDL cholesterol), smooth muscle cells and lymphocytes within the arterial wall in response to the release of pro-inflammatory molecules. Thus, the host immune system plays an essential role in the development of the atherosclerotic plaque. This can be stimulated by certain molecules of the host, such as oxidized low-density lipoprotein (oxLDLs), lipoprotein a (Lpa) or foreign antigens, including the ones of certain bacteria (7).

\section{Oral pathogens in atheromatous plaque}

The most typical oral pathogens associated with human $\mathrm{PD}$ are Porphyromonas gingivalis (Pg), Actinobacillus actinomycetemcomitans (Aa) and Streptococcus sanguis (Ss), which can all invade the junctional epithelium and gain access to the systemic circulation.

Possible mechanisms by which oral pathogens can contribute to CVD are by a direct effect on the formation of 
the atherosclerotic plaque in the endothelium; by an indirect effect mediated by the host immune response (5); or by a genetic predisposition for pathogenesis (1).

Some academics found a causal relationship between PD and CVD. They support the etiopathogenic model in which periodontal bacteria such as $\mathrm{Aa}$ and $\mathrm{Pg}$, once in the bloodstream (bacteremia), would stimulate by an indirect effect the release of antibodies (5), cytokines and other pro-inflammatory mediators such as CRP or TNF $\alpha$ (6). They would be responsible for initiating a cascade of biochemical reactions, causing endothelial damage and ultimately facilitating the genesis of the atherosclerotic plaque (1).

Other studies have pointed out the presence of $\mathrm{Pg}$ at the atheromatous plaque $(3,7-11)$. This microorganism enters the vascular system and settles in areas of the developing atherosclerotic plaque. This could aggravate the
CVD (by a direct effect). The Pg possesses numerous virulence factors such as proteases, lipopolysaccharides, capsular polysaccharides, hemagglutinins and fimbriae (12). In vitro studies have shown that the fimbriae of this microorganism plays a pivotal role in the invasion and adhesion to endothelial cells (10), in stimulating the production of cell adhesion molecules (VCAM) and the expression of chemokines (13). In addition, the $\mathrm{Pg}$ is a producer of proteases that can activate platelet aggregation and stimulate the coagulation cascade. Thereby it contributes to the disruption of the atherosclerotic plaque and thrombotic complications $(1,10)$. Platelet receptors have been described for a PG antigen (14). This fact would determinate their aggregation, the capability of some periodontal pathogens to invade the endothelium and their DNA presence at the atheromatous plaque. Lourbakos et al. (14) found an association between Pg and

\begin{tabular}{|c|c|c|c|c|c|}
\hline Authors & $\begin{array}{l}\text { Type } \\
\text { study }\end{array}$ & (n) & $\begin{array}{c}\mathrm{CV} \\
\text { parameters }\end{array}$ & $\begin{array}{l}\text { Periodontal } \\
\text { parameters }\end{array}$ & Confounding factors \\
\hline $\begin{array}{l}\text { Yamazaki et } \\
\text { al. (2007) }\end{array}$ & Pc-c & $\begin{array}{l}\text { CHD: } 51 ; \\
\text { PD: } 55 ; \\
\text { healthy: } 37\end{array}$ & $\begin{array}{l}\text { Chronic sta- } \\
\text { ble angina/ } \\
\text { ACS }\end{array}$ & $\begin{array}{l}\mathrm{PD}, \mathrm{JEL}, \mathrm{BL}, \mathrm{n}^{\mathrm{o}} \\
\text { teeth }\end{array}$ & $\begin{array}{l}\text {-Age - gender - smoking, - lipid pro- } \\
\text { file - antibodies }\end{array}$ \\
\hline $\begin{array}{l}\text { Spar et al. } \\
(2006)\end{array}$ & Pc-c & $\begin{array}{l}\text { CHD: 263; } \\
\text { C:526 }\end{array}$ & $\begin{array}{l}\text { Stable } \mathrm{CHD} / \\
\text { history } \mathrm{MI} / \\
\text { history } \mathrm{HBP}\end{array}$ & CPITN, SBS & $\begin{array}{l}\text {-Age - gender - smoking - BMI - al- } \\
\text { cohol - hyperlipoproteinemia - dia- } \\
\text { betes mellitus - exercising - choles- } \\
\text { terol - school education }\end{array}$ \\
\hline $\begin{array}{l}\text { Pussinen et al. } \\
\text { (2003) }\end{array}$ & $\mathrm{P}$ & 1163 & CHD & Teeth (n) & $\begin{array}{l}\text {-Smoking - alcohol - HBP - lipid } \\
\text { profile - cholesterol - education }\end{array}$ \\
\hline $\begin{array}{l}\text { Ishihara et al. } \\
(2004)\end{array}$ & Pd-b & CHD: 51 & $\begin{array}{l}\text { Plaques in } \\
\mathrm{CA}\end{array}$ & $\begin{array}{l}\text { PD, periodontal } \\
\text { lesions, SBS }\end{array}$ & - \\
\hline $\begin{array}{l}\text { Pussinen et al. } \\
\text { (2004) }\end{array}$ & Pc-c & 6950 & $\begin{array}{l}\text { Histroy MI/ } \\
\text { CHD }\end{array}$ & - & $\begin{array}{l}\text {-Age - gender - smoking - HBP - } \\
\text { BMI - alcohol - diabetes - choles- } \\
\text { terol }\end{array}$ \\
\hline $\begin{array}{l}\text { Beck et al. } \\
(2005)\end{array}$ & Pc & 15792 & CHD history & SBS, CFS, PD & $\begin{array}{l}\text {-Age - gender - smoking - HBP - } \\
\text { diabetes - LDL/HDL cholesterol - } \\
\text { rece }\end{array}$ \\
\hline $\begin{array}{l}\text { Pussinen et al. } \\
(2007)\end{array}$ & $\mathrm{Pc}$ & 6051 & $\begin{array}{l}\text { CHD preva- } \\
\text { lence/ CHD } \\
\text { incidence/ } \\
\text { non-CHD } \\
\text { death. }\end{array}$ & - & $\begin{array}{l}\text {-Age - gender - total serum choles- } \\
\text { terol - HDL }\end{array}$ \\
\hline $\begin{array}{l}\text { Demmer et al. } \\
(2010)\end{array}$ & Pc & 706 & CHD & $\begin{array}{l}\mathrm{N}^{\circ} \text { teeth, } \mathrm{PD}, \\
\text { gingival margin } \\
\text { location, } \mathrm{BL}, \mathrm{Pd} \text {. }\end{array}$ & - \\
\hline $\begin{array}{l}\text { Sakurai et al. } \\
\text { (2007) }\end{array}$ & $\mathrm{P}$ & CHD: 28 & Ca measure & $\mathrm{PD}, \mathrm{B}$ & - \\
\hline
\end{tabular}

Table 1. Description of the most relevant clinical studies.

P: Prospective; P c-c: Prospective case-control; Pc: Prospective cohort; Pb: Prospective double blind C: control; CHD: Coronary heart disease; ACS: Acute Coronary Syndrome; MI: myocardial infarction ; Ca: coronary angiography; CA: coronary arteries; CPITN: Community Periodontal Index of Treatment Needs; HBP: high blood pressure; SP: systolic pressure ; HDL: high density lipoprotein cholesterol; LDL: low density lipoprotein cholesterol; BMI: body mass index; CRP: C-reactive protein; PD: probing depth; Pd: pocket depth; BL: bone loss; B: Bleeding; JEL: junctional epithelium level; SBS: subgingival biofilm sample; CFS: crevicular fluid samples 
CVD through the production of a proteinase (argininegingipains) that can activate protease receptors PAR-1 and PAR-4 which are evidenced on the platelet surface. In a recent study, Roth et al. (11) discussed for the first time the capability of the Pg to invade smooth muscle cells of blood vessels and modulate the production of the Tissue Factor (TF) and its inhibitor (TFPI). They found that the Pg was able to decrease the production and activity of TFPI and enhance the production and activity of TF. They noticed that this periodontal pathogen has prothrombotic effects by acting on smooth muscle cells, modulating the production TFPI. From another clinical study emerged that hemagglutinins are involved in the adhesion of Pg to endothelial cells of human coronary arteries (15).

\section{Experimental studies on animals}

Experimental studies have been useful to clarify the pathogenic models of bacterial action on atherogenesis. Some in vivo studies on animals $(10,13,20,22)$ discovered that individuals who were inoculated periodontal microorganisms had more advanced and larger atherosclerotic lesions, which were developed before, than the animals from the control group.

Genco et al. (2) suggested that Pg infection, which is one of the most important pathogens associated with human $\mathrm{PD}$, activates the acute response of systemic inflammation, increases lipaemia and enhances atherosclerotic lesion formation in ApoE (+/-) mice (heterozygous genotype).

Chi et al. (18) observed on their experimental study on mice that interleukin 1 (IL-1) promotes atherogenesis. This is due to the analysis of post-mortem atheromatous plaque samples, which indicated that mice without IL-1 receptor (ApoE +/-/IL-1R1 -/-) had smaller atheromatous lesions than ApoE +/-/IL-1R1 +/- mice. Madan et al. (19) experimented about ApoE (+/-) mice as well. They found that ApoE +/-/IL-6 -/- mice had a significant increase on the aortic atheromatous lesions, higher levels of acute coronary syndrome (ACS) and pro-inflammatory cytokines compared with ApoE +///IL-6 +/group. These results insinuate that IL-6 has a protective function against atherosclerosis. Miyamoto et al. (17) became aware of more advanced atheromatous damages at hyper-lipemic mice.

In addition, Brodala et al. (20) detected Pg DNA at atheromatous plaques on carotid and aortic artery vascular tissues in pigs. These animals were given a high-fat diet and were inoculated a Pg infection. Bacteremia by Pg induced atherosclerosis in pigs with normal cholesterol levels, and increased atherosclerosis in pigs with high cholesterol levels. It seemed that PD enhanced the accumulation of lipids in vivo, due to chronic inflammation. Therefore, it is believed that the infectious agent by itself does not cause atherosclerosis, but it does contribute to accelerate its progression when this damage is al- ready formed (21). In another study on animals (13), the experts checked also that immunization (vaccination) against Pg prevents the atherosclerosis acceleration.

However, not all the studies proof finding this causality. Miyamoto et al. (17) for instance, could not demonstrate during their experimental study on mice that infection by Pg could cause an important systemic inflammatory reaction. They studied the levels of IL-6 and Amyloid A (the equivalent of CRP in humans) on serological samples of Pg infected and non-infected mice, and they found very similar levels on both groups.

\section{Clinical studies on humans}

Several clinical studies on humans reveal that some pathogens of bacterial plaque have a direct effect on atherosclerosis even though some study designs are more appropriate than others when it comes to look for the causality relation between PD and CVD (Table 1).

Meurman et al. (1) summarize on their literature review the necessary criteria to establish the causality between these phenomena (PD-CVD) (Table 2).

IgG antibody measurement is one of the most used factors with the aim of setting a causal link between PD and atherosclerosis. In some studies they took samples from sub-gingival biofilm and made a serologic analysis, in which they detected antibodies against periodontal pathogens $(3,5,22-24)$. An association between these pathogens and atherosclerosis (coronary disease specifically) was found after adjusting other risk factors for CVD. However, this fact could not prove a cause-effect relation.

Pussinen et al. (5), on their transversal cohort study, found a link between IgG against Pg and $\mathrm{Aa}$, and ischemic cardiopathy (IC). They noticed greater prevalence of IC in those subjects with high IgG levels than in those with low levels. They related edentulism and seropositivity to Pg with IC. With lineal regression, they observed that the antibody reaction was associated directly with the prevalence of IC. Sakurai et al. (16) thought that Aa could play a determinant role in the development of acute coronary syndrome (ACS). This is because they found Aa at the oral plaque samples taken from subjects with ACS. Contrastingly, the counts were negative in subjects who suffered chronic ischemic cardiopathy (CIC).

Demmer et al. (25), in a very recent cohort prospective study, analyzed the periodontal infection as a risk factor for CVD, by the study of periodontal clinical parameters, using them as a substitute for the underlying bacterial exposure. They found that the periodontal clinical measures which demonstrated greater link with bacteria charges were: rate of bleeding points after probing $(\mathrm{r}=0.62)$; number of locations with bleeding after probing $(\mathrm{r}=0.59)$ and rate of locations with probing depth (PD) $\geq 3 \mathrm{~mm}(\mathrm{r}=0.61)$, whereas $\mathrm{PD} \geq 8 \mathrm{~mm}, \mathrm{r}=0.16$. This fact could demonstrate that the clinical definition for $P D$ should include the low-depth periodontal pocket measu- 


\begin{tabular}{|c|c|c|}
\hline & Interpretation & Comments \\
\hline Temporal relationship: & $\begin{array}{l}\text { Does the predictor occur before } \\
\text { the results? }\end{array}$ & This criterion must be met in any case. \\
\hline Response according to the dose: & $\begin{array}{l}\text { When there is greater severity of } \\
\text { the predictor, are there more se- } \\
\text { vere results? }\end{array}$ & $\begin{array}{l}\text { This is not always the case. Some causal } \\
\text { relationships occur in a threshold at which } \\
\text { the results can be different: illness or dis- } \\
\text { ease. }\end{array}$ \\
\hline Strength of association: & $\begin{array}{l}\text { Is the morbidity rate higher in the } \\
\text { exposed tan in unexposed? }\end{array}$ & $\begin{array}{l}\text { Some risk factors generate very high-risk } \\
\text { relationship } \\
\text { (e.g. smoking). }\end{array}$ \\
\hline Consistence: & $\begin{array}{l}\text { Do the investigations carried out } \\
\text { in different countries, groups or } \\
\text { institutions generate similar re- } \\
\text { sults? }\end{array}$ & $\begin{array}{l}\text { Results could not be consistent, due to } \\
\text { the investigation methods (clinical or } \\
\text { epidemiological) or to the adjustment for } \\
\text { confounding factors. Especially if the pre- } \\
\text { dictor is weak and the confounding factors } \\
\text { are strong. (Pay special attention to the } \\
\text { false "true associations") }\end{array}$ \\
\hline Biology: & Does it make biological sense? & $\begin{array}{l}\text { The pathogenesis is important. Do we } \\
\text { have a solid biological reason to believe } \\
\text { that there is a causation or association? } \\
\text { This must always be complied. }\end{array}$ \\
\hline
\end{tabular}

Table 2. Criteria for establishing a causal association. Table of Hennekens and Buring (1987), adjusted by Meurman JH.

res in order to show better the relationship between PD and bacteria rates.

Pussinen et al. (6) carried out a cohort prospective study with a sample of 6,051 participants with the aim of relating serologic endotoxins, IgG against periodontal pathogens and inflammation markers (IL-6, CRP) in relation with CVD. They took samples of endotoxins and serologic antibodies from 784 collaborators. High levels of endotoxins were related positively with diastolic pressure, total cholesterol, body mass index (BMI) and IgG against Pg. During ten years of monitoring, they realized that those individuals who suffered any episode of CVD had higher blood levels of endotoxins. High concentration of endotoxins, antibodies, CRP and IL-6 are directly associated with cardiovascular episodes when adjusted by age and gender. They came to the conclusion that high IgG levels against Aa and Pg could be considered as a cardiovascular risk factor in the future, researchers studied people who had suffered myocardial infarction (MI), and they found a serological evidence of an association with PD (4).

In another cohort prospective study (6) the atheromatous plaques of 51 patients, which had to be operated surgically, were analyzed. The presence of 5 microorganisms come into view in both the atheromatous plaque of the coronary arteries and the subgingival plaque: $\mathrm{Aa}, \mathrm{Pg}$, Bacteroides forsythus, Treponema denticola and Campylobacter rectus. Therefore, PD was related directly to the detection of periodontal bacteria DNA in atheroma- tous lesions. The DNA identification of those pathogens at the atheromatous plaque was carried out with polymerase chain reaction (PCR), immunofluorescence and electronic microscopy techniques $(3,8)$.

It seems that atherosclerosis is an inflammatory nature disease more than a disease caused by an excess in lipid deposit. Equally, PD is a consequence of the host inflammatory reaction more than a direct destruction from the pathogens infection. It has been observed that chronic infections cause possible bacteremia which lead to the attack and activation of endothelial cell inflammation caused by periodontal pathogens as Pg. The studies accomplished, however, have not been able to isolate viable bacteria, but just their sequence of nucleic acids. This supports the evidence that chronic infections help generate a modification in the regulation of the inflammatory response. This in turn provokes a further alteration of endothelial cells on the one hand and acceleration in the formation of atheromatous plaques on the other (26). In PD there would be an over regulation of certain inflammation markers such as CRP or soluble E-selectin. By reducing these bio-markers and controlling local and systemic inflammation, endothelial dysfunction and the risk of CVD would decrease $(26,27)$.

At the vessel wall, after endothelial injury, monocytes and lymphocytes migrate into the blood vessel wall, led by inflammation signs. Then monocytes differ into macrophages, which recognize and phagocytose LDLcholesterol particles. These monocytes, process and pre- 
sent the protein component of LDL particles as a peptide to T-lymphocytes, by the major histocompatibility complex II (MHC II). Other antigens, own or strangers, which have access to the vessel wall as well, could trigger a similar mechanism. It is believed that most lymphocytes differ in situ into effector T- lymphocytes, under the influence of stimuli from specific antigens; this, nevertheless still needs to be proved. Once they have been activated, macrophages and lymphocytes initiate the release of pro-inflammatory molecules (chemokines), which can stimulate the migration of smooth muscle cells from the intermediate layer of the vessel. This, together with the formation of foamy cells, is going to initiate the formation of the fibrous layer. This process is facilitated by cytokines such as TNF $\alpha$ and IL-12, secreted by macrophages and foamy cells. Foamy cells then die by in situ apoptosis, releasing non-degradable cholesterol crystals, which become part of the core of the future atheromatous plaque.

\section{Discussion}

CVD is the most common cause of death in developed countries. The classic factors that predispose to CVD are identified: dyslipidemia, genetics, age, gender, high blood pressure, smoking, diabetes mellitus and metabolic syndrome. Obvious risk factors for CVD such as obesity and stress also appear to be related to PD. However, we must consider the emerging risk factors as biological markers: homocysteine, atherogenic lipoproteins, CRP and fibrinogen. These two factors reflect the levels of low intensity chronic systemic inflammation, as in the case of PD. This could be related to an increased risk of CVD (4-6). In fact, the PD-CVD association has been one amidst the most studied in recent years (7).

However, this link is difficult to prove because both diseases share common risk factors (age, gender, smoking, oral hygiene habits or diabetes mellitus). In previous reviews on the subject, some experts $(1,2)$ warned of the need to be cautious when affirming a causal relationship between PD-CVD, due to the difficulty of drawing conclusions based on the results of the studies reviewed . Besides, there are confounding factors that may not have been taken into consideration in certain clinical studies included in this review. In addition, the criteria for CVD and the diagnostic parameters for PD for each study could be different.

The determination of bacterial species, bacterial proteins and lipopolysaccharide in the atheromatous plaques which block coronary arteries has raised speculation about the origin of these bacteria and what their reservoir is, finding that one of the possible places is the periodontal pocket (16). It has been observed that the distribution of periodontal pathogens in the gingival biofilm is closely related to the levels of antibodies against these bacteria in blood (5).
Periodontal bacteria would enter the bloodstream through the micro ulceration of the epithelium of the periodontal pocket. This entails a long-term systemic exposure of these pathogens. Once in the general circulation, they could play a direct or indirect role in the progression of atherosclerotic plaques in arterial lesions (16). The antiinfective periodontal therapies, not only improve the clinical symptoms, but also improve local antioxidant status and systemic vascular endothelial dysfunction (28). This was evident in experimental studies. As such by inoculating periodontal bacteria they observed greater vascular lesions. Through the increase of blood lipids systemic inflammation activates atherogenesis. This is the reason why periodontal diseases could enhance the accumulation of lipids and thus generate chronic inflammations. The infectious agent by itself does not cause atherosclerosis, but seems to help accelerate its progression when the lesion is formed (12-14).

In clinical studies, one of the methods used to validate the association between periodontal bacteria and the atheromatous plaque has been the detection of antibodies against periodontal micro-organisms (5). Bacterial endotoxin and inflammatory mediators in relation to atheromatous lesions have been detected as well.

In addition, the DNA of microorganisms present in the bacterial plaque and in the atheromatous lesion has been directly identified. Finally, scientists have tried to relate directly the level of clinical periodontal lesions (bleeding and pocket depth) with the level of inflammation and cardiovascular injury (25).

There is plenty of epidemiological evidence with the data provided to date. This seems to confirm the role of periodontal damage by oral pathogens as a factor in the development of atherosclerosis. Yet, the quantification of this association remains unknown.

\section{References}

1. Meurman JH, Sanz M, Janket SJ. Oral health, atherosclerosis, and cardiovascular disease. Crit Rev Oral Biol Med. 2004; 15: 403-13.

2. Genco R, Offenbacher S, Beck J. Periodontal disease and cardiovascular disease: Epidemiology and possible mechanisms. J Am Dent Assoc. 2002; 133 Suppl: 14S-22S

3. Spahr A, Klein E, Khuseyinova N, Boeckh C, Muche R, Kunze $\mathrm{M}$, et al. Periodontal infections and coronary heart disease: role of periodontal bacteria and importance of total pathogen burden in the Coronary Event and Periodontal Disease (CORODONT) study. Arch Intern Med. 2006; 166: 554-9.

4. Pussinen PJ, Alfthan G, Rissanen H, Reunanen A, Asikainen S, Knekt P. Antibodies to periodontal pathogens and stroke risk. Stroke. 2004; 35: 2020-3.

5. Pussinen PJ, Jousilahti P, Alfthan G, Palosuo T, Asikainen S, Salomaa V. Antibodies to periodontal pathogens are associated with coronary heart disease. Arterioscler Thromb Vasc Biol. 2003; 23 : 1250-4.

6. Pussinen PJ, Tuomisto K, Jousilahti P, Havulinna AS, Sundvall J, Salomaa V. Endotoxemia, immune response to periodontal pathogens, and systemic inflamation associate with incident cardiovascular disease events. Arterioscler Thtromb Vasc Biol. 2007; 27 : 1433-9.

7. Milioti N, Bermudez-Fajardo A, Penichet ML, Oviedo-Orta E. Re- 
view article: antigen-induced immunomodulation in the patogénesis of aterosclerosis. Clin Dev Inmunol. 2008; 2008: 723539.

8. Cavrini F, Sambri V, Moter A, Servidio D, Marangoni A, Montebugnoli L, et al. Molecular detection of Treponema denticola and Porphyromonas gingivalis in carotid and aortic atheromatous plaques by FISH: report of two cases. J Med Microbiol. 2005; 54: 93-6.

9. Ishihara K, Nabuchi A, Ito R, Miyachi K, Kuramitsu HK, Okuda $\mathrm{K}$. Correlation between detection rates of periodontopathic bacterial DNA in carotid coronary stenotic artery plaque and in dental plaque samples. J Clin Microbiol. 2004; 42: 1313-5.

10. Brodala N, Merricks EP, Bellinger DA, Damrongsri D, Offenbacher S, Beck J, et al. Porphyromonas gingivalis bacteremia induces coronary and aortic atherosclerosis in normocholesterolemic and hypercholesterolemic pigs.Arterioscler Thromb Vasc Biol. 2005; 25: 1446-51.

11. Roth GA, Aumayr K, Giacona MB, Papapanou PN, Schmidt AM, Lalla E. Porphyromonas gingivalis infection and prothrombotic effects in human aortic smooth muscle cells. Thromb Res. 2009; 123: $780-4$.

12. Ogawa T. Immunogiological properties of chemically defined lipid A from lipopolisaccharide of Porphiromonas (Bacteroides) gingivalis. Eur J Biochem. 1994; 219:737-42.

13. Gibson FC, Hong C, Chou H, Yumoto H, Chen J, Lien E, et al. Innate immune recognition of invasive bacteria accelerates atherosclerosis in apolipoprotein E-deficient mice. Circulation. 2004; 109: 2801-6.

14. Lourbakos A, Yuan YP, Jenkins AL, Travis J, Andrade-Gordon P, Santulli R, et al. Activation of protease-activated receptors by gingipains fron Porphyromonas gingivalis leads to platelet aggregation: a new trait in microbial pathogenicity. Blood. 2001; 97:3790-7.

15. Song H, Bélanger M, Whitlock J, Kozarov E, Progulske-Fox A. Hemaglutinin B is involved in the adherence of Porphyromonas gingivalis to human coronary artery endothelial cells. Infect Immun. 2005; 73: 7267-3.

16. Sakurai K, Wang D, Suzuki J, Umeda M, Nagasawa T, Izumi Y, et al. High incidente of actinobacillus actinomycetemcomitans infection in acute coronary syndrome. Int Heart J. 2007; 48: 663-75.

17. Miyamoto T, Yumoto H, Takahashi Y, Davey M, Gibson FC 3rd, Genco CA. Pathogen-accelerated atherosclerosis occurs early after exposure and can be prevented via immunization. Infect Immun.2006; 74:1376-80.

18. Chi H, Messas E, Levine RA, Graves DT \& Amar S. Interleukin-1 receptor signaling mediates atherosclerosis associated with bacterial exposure and /or a high-fat diet in a murine apolipoprotein $\mathrm{E}$ heterozygote model: pharmacotherapeutic implications. Circulation. 2004; 110: 1678-85.

19. Madan M, Bishayi B, Hoge M \& Amar S. Atheroprotective role of interleukin-6 in diet- and/or pathogen-associated atherosclerosis using an ApoE heterozygote murine model. Atherosclerosis. 2008; 197:504-14

20. Brodala N, Merricks EP, Bellinger DA, Damrongsri D, Offenbacher S, Beck J, et al. Porphyromonas gingivalis bacteremia Induces coronary and aortic atherosclerosis in normocholesterolemic and hypercholesterolemic pigs. Arterioscler Thromb Vasc Biol. $2005 ; 25 ; 1446-51$.

21. Li L, Messas E, Batista EL Jr, Robert A. Porphyromonas gingivalis infection accelerates the progression of aterosclerosis in a heterozygous apolipoprotein E- deficient murine model. Circulation. 2002; 105: 861-7.

22. Yamazaki K, Honda T, Domon H, Okui T, Kajita K, Amanuma R, et al. Relationship of periodontal infection to serum antibody levels to periodontopathic bacteria and inflammatory markers in periodontitis patients with coronary heart disease. Clin Exp Immunol. 2007; 149: 445-52.

23. Beck JD, Eke P, Heiss G, Madianos P, Couper D, Lin D, Moss K, et al. Periodontal disease and coronary heart disease: A reappraisal of the exposure.Circulation. 2005; 112: 19-24.
24. Pussinen PJ, Nyyssönen, Alfthan G, Salonen R, Laukkanen JA, Salonen JT. Serum antibody levels to Actinobacillus actinomycetemcomitans predict the risk for coronary heart disease. Arterioescler Thromb Vasc Biol. 2005; 25: 833-8.

25. Demmer RT, Papapanou PN, Jacobs DR Jr, Desvarieux M. Evaluating clinical periodontal measures as surrogates for bacterial exposure: the Oral Infections and Vascular Disease Epidemiology Study (INVEST). BMC Med Res Methodol. 2010; 10:2.

26. Davé S, Van Dyke TE. The link between periodontal disease and cardiovascular disease is probably inflammation. Oral Dis. 2008; 14:95-101.

27. Tonetti MS, D'Aiuto F, Nibali L, Donald A, Storry C, Parkar M, et al. Treatment of periodontitis and endothelial function. $\mathrm{N}$ Engl $\mathrm{J}$ Med. 2007; 356:911-20.

28. Matthews JB, Wright HJ, Roberts A, Ling-Mountford N, Cooper PR, Chapple IL. Neutrophil hyper-responsiveness in periodontitis. J Dent Res.2007; 86:718-22. 